\section{OPEN ACCESS}

Edited by: Annunziata Giangaspero, University of Foggia, Italy

Reviewed by: Scala Antonio,

University of Sassari, Italy Jozef Vercruysse,

Ghent University, Belgium

${ }^{*}$ Correspondence: Laura Rinald Irinaldi@unina.it

Specialty section: This article was submitted to Parasitology,

a section of the journal

Frontiers in Veterinary Science

Received: 25 April 2020

Accepted: 09 June 2020

Published: 04 August 2020

Citation:

Morgoglione ME, Bosco A Maurelli MP, Alves LC, Saralli G, Bruni G, Cringoli $G$ and Rinaldi $L$ (2020) A 10-Year Surveillance of Eimeria spp. in Cattle and Buffaloes in a Mediterranean Area. Front. Vet. Sci. 7:410 doi: 10.3389/fvets.2020.00410

\title{
A 10-Year Surveillance of Eimeria spp. in Cattle and Buffaloes in a Mediterranean Area
}

\section{Maria Elena Morgoglione ${ }^{1}$, Antonio Bosco ${ }^{1}$, Maria Paola Maurelli ${ }^{1}$, Leucio Camara Alves ${ }^{2}$, Giorgio Saralli ${ }^{3}$, Gianpaolo Bruni ${ }^{3}$, Giuseppe Cringoli ${ }^{1}$ and Laura Rinaldi ${ }^{1 *}$}

\footnotetext{
1 Department of Veterinary Medicine and Animal Production, University of Naples Federico II, CREMOPAR Campania Region, Naples, Italy, ${ }^{2}$ Department of Veterinary Medicine, Federal Rural University of Pernambuco, Recife, Brazil, ${ }^{3}$ stituto

Zooprofilattico Sperimentale del Lazio e della Toscana M. Aleandri, Rome, Italy
}

Coccidiosis due to Eimeria spp. are widespread parasitic infections in cattle and water buffaloes and may impair health, welfare, and production of these livestock species. The aims of this study were (i) to investigate the prevalence and seasonal dynamics of eimeriosis and (ii) to characterize the Eimeria species in large ruminants in a Mediterranean area, in order to plan effective control strategies. Parasitological data were obtained from a 10-year surveillance program (2010-2019) on 3,631 farms (2,089 buffalo and 1,542 cattle farms) sampled in central and southern Italy. Pooled fecal samples were analyzed using the FLOTAC technique with an analytic sensitivity of 2 oocysts per gram of feces (OPG) utilizing a saturated sodium chloride flotation solution (specific gravity $=1.200$ ). Eimeria species identification was performed by morphometric analysis after a one week incubation of oocysts in a $2.5 \%$ potassium dichromate solution. The results showed high prevalence of Eimeria (up to 100\%) in both cattle and buffaloes in the 10 years of surveillance, even if a slight reduction was reported in the last three years. The overall prevalence of eimeriosis was $91.7 \%$ (95\% confidence interval, $95 \% \mathrm{Cl}=90.2-93.1)$ in cattle farms and $81.5 \%(95 \% \mathrm{Cl}=79.8-$ 83.1) in water buffalo farms. The mean OPG value was 66.8 ( $\min =2$; $\max =8,065)$ in cattle and 55.9 ( $\min =2$; $\max =15,415$ ) in water buffaloes, but this difference was not statistically significant $(p>0.05)$. In total, nine species of Eimeria were found in cattle the most prevalent being Eimeria bovis, E. ellipsoidalis, E. cylindrica, and E. zuernii, whereas in water buffaloes eight species of Eimeria were found, the most prevalent being E. ellipsoidalis, E. auburnensis, E. bovis, and E. zuernii. Mixed infections were common in both ruminant species. The seasonal pattern showed a higher prevalence of eimeriosis in cattle in spring (86.9\%) whereas in buffalo farms the prevalence was higher in winter (82.3\%) and summer (82.4\%). In conclusion, the 10-year surveillance program indicates that eimeriosis is common in cattle and water buffaloes and therefore continuous effective control strategies are needed.

Keywords: eimeriosis, seasonal dynamics, cattle, buffaloes, Mediterranean area 


\section{INTRODUCTION}

Coccidiosis due to Eimeria spp. are widespread parasitic infections in cattle and water buffaloes and may impair health, welfare, and production of these livestock species (1-3). Animals become infected by the horizontal route, ingesting sporulated oocysts from contaminated feed, water, or pasture or by licking contaminated hair coat $(1,3,4)$. Outbreaks in cattle and water buffaloes are associated with several factors, including the species of Eimeria, the age of the animals, immunological status of hosts, the dose of the oocysts ingested, and farm management and environmental factors (5-7).

More than 20 Eimeria species are described in cattle (8), and among them, 12 species can affect also water buffaloes (Bubalus bubalis) $(9,10)$ although coccidia are usually hostspecific parasites. E. zuernii, E. bovis, and E. auburnensis are the most pathogenic species in both hosts worldwide $(11,12)$, while $E$. bareillyi is a pathogenic species specific only for water buffaloes (13).

Usually adult animals are asymptomatic, although they can be a reservoir for younger ones $(14,15)$, whereas calves can show gastrointestinal (GI) signs, such as diarrhea, dysentery, dehydration, debilitation, and even death $(5,8)$.

Compared with cattle, there is limited scientific knowledge about the health of water buffaloes so updated data on parasitic infections (as eimeriosis) is an interesting challenge in this species where knowledge regarding the health consequences of the most common pathologies as well as their economic impact on the entire dairy food chain are still almost rare (16).

Indeed, considering the health and welfare implications, as well as the economic losses due to Eimeria infections in ruminant livestock, the knowledge of their geographical distribution, prevalence, and intensity of infection is important to understand the dynamic of infection in relation to biotic (such as age) and abiotic (such as seasonality) factors (6) especially in areas where dairy cattle and water buffalo farms coexist and play a major role for the economy of the region (16). The published studies on eimeriosis in large ruminants in Italy are few and focused mainly on treatment (17-19), while the epidemiological data in Europe are scarce, not updated, and focused only on cattle (11, 20-23).

For these reasons, the aims of this study were (i) to investigate the prevalence and seasonal dynamics of eimeriosis and (ii) to speciate the Eimeria in large ruminants in a Mediterranean area, in order to plan effective control strategies.

\section{MATERIALS AND METHODS}

\section{Study Area and Design}

The study was conducted in three Italian regions: Lazio (latitude $=41^{\circ} 53^{\prime} 35^{\prime \prime} \mathrm{N}$; longitude $=12^{\circ} 28^{\prime} 58^{\prime \prime} \mathrm{E}$ ) in the Center, Campania (latitude $=40^{\circ} 49^{\prime} 34^{\prime \prime} \mathrm{N}$; longitude $=14^{\circ} 15^{\prime} 23^{\prime \prime} \mathrm{E}$ ) and Basilicata (latitude $=40^{\circ} 38^{\prime} 21^{\prime \prime} \mathrm{N}$; longitude $=15^{\circ} 48^{\prime} 19^{\prime \prime} \mathrm{E}$ ) in the South. The study area extends over $40,898 \mathrm{~km}^{2}$ from the Apennines to the Tyrrhenian Sea where cattle and water buffaloes are bred. The entire area is characterized by high heterogeneity with hills and mountains inland and lowlands mainly near the coast. This area is characterized by mild and wet autumns/winters with an average monthly temperature of $9^{\circ} \mathrm{C}$ and hot and dry springs/summers with an average monthly temperature of $22^{\circ} \mathrm{C}(24)$.

Parasitological data were obtained by the Regional Centre for Monitoring of Parasitosis (CREMOPAR, Campania Region, Southern Italy) from a 10-year program (2010-2019) of active and passive surveillance on 3,631 farms (cattle and water buffalo farms) (Figure 1). Data related to cattle farms in the Lazio region and water buffalo farms in the Basilicata region were fragmented, so they were not included in the study. Moreover, analysis of yearly prevalence and seasonal dynamics of cattle and buffalo coccidiosis was performed only in Campania region, because full data were available through all the years of this study, due to the continuous monitoring service offered by the Department of Agriculture of the Campania Region, through the activities of CREMOPAR.

\section{Farm Management Cattle Farms}

Cattle (Bos indicus and B. taurus) are the most common world widespread species of large ruminant livestock. Cattle are raised in diverse production systems ranging from capital-intensive, specialized beef and dairy grass-based and feedlot systems (25).

In the study area, cattle are raised for meat and/or milk production. The dairy farms are characterized by an intensive farming system, with suitable buildings and modern equipment to guarantee animal welfare, in order to maximize the production (26). On the other hand, the meat production is mainly characterized by an extensive farming system, with daily grazing and sheltering in part-time housing. This system allows the animals to graze on poor soils with minimal vegetation. In the study area, the two productive realities coexist: dairy farms are spread in the plain and in the foothills area, while the beef cattle are on grazing and marginal land. The Italian cattle population amounts to more than 5 million onto 145,363 farms (Figure 2A). The numbers of cattle farms in Campania and Basilicata represent $7.3 \%$ and $1.9 \%$ of the Italian farms, respectively (National Data Bank-NDB at 31th December 2019).

\section{Buffalo Farms}

Water buffalo (B. bubalis) farming is important for the economy of several countries, including Brazil, China, India, Vietnam, and Italy. Mozzarella cheese manufacturing from milk of water buffalo is third-ranked in sales volume in Italy (27). The modern intensive water buffalo breeding is likely to replace the cattle breeds and has almost completely replaced the traditional free-range/semi-free-range buffalo farming $(21,28)$. Currently, the buffalo management is characterized by technologically advanced and automatic systems (e.g., milking robots, automatic manure cleaning, the use of the pedometer for individual measurements of physiological/production parameters, etc.). The southern provinces of Lazio (Latina and Frosinone), the Campania region, and other two southern provinces not included in the study area (Foggia and Isernia) represent the area of buffalo mozzarella cheese with the Protected Designation of Origin (PDO) mark (29). In Italy, there are 2,711 buffalo farms (Figure 2B) with a total of 402,796 animals. Lazio and Campania 


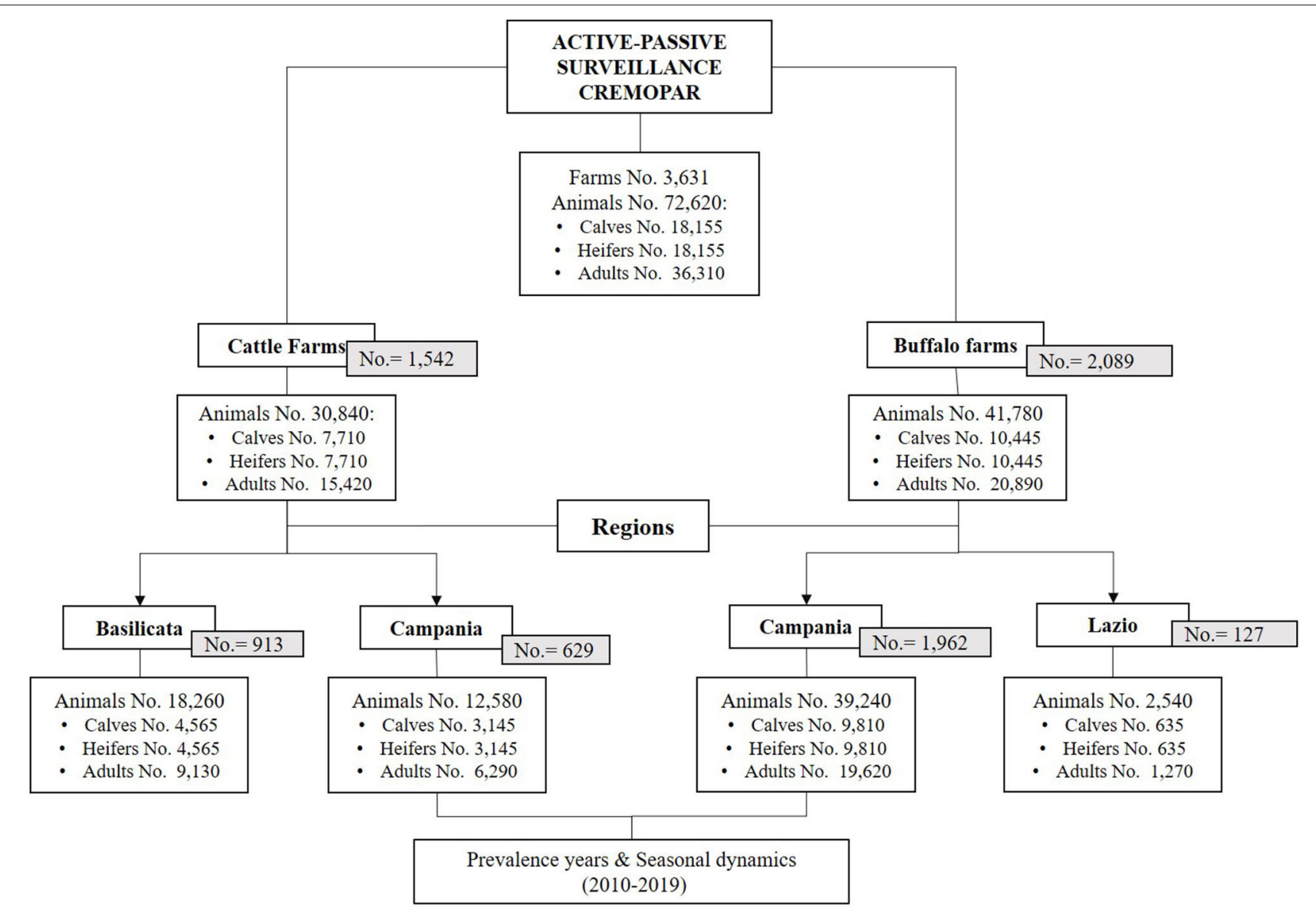

FIGURE 1 | Study setup of the analyzed data from the 10-year surveillance program, with the total number of cattle and water buffalo farms, total number of animals, and age categories in the Italian regions involved (Lazio, Campania, and Basilicata).

A

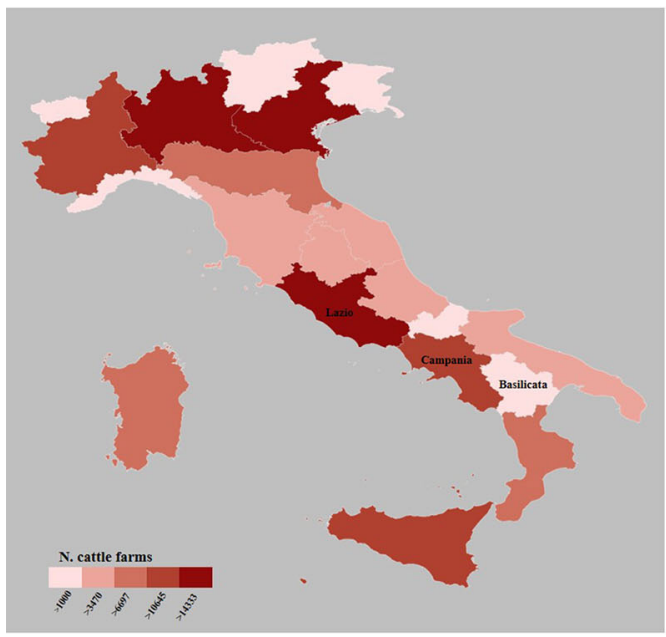

B

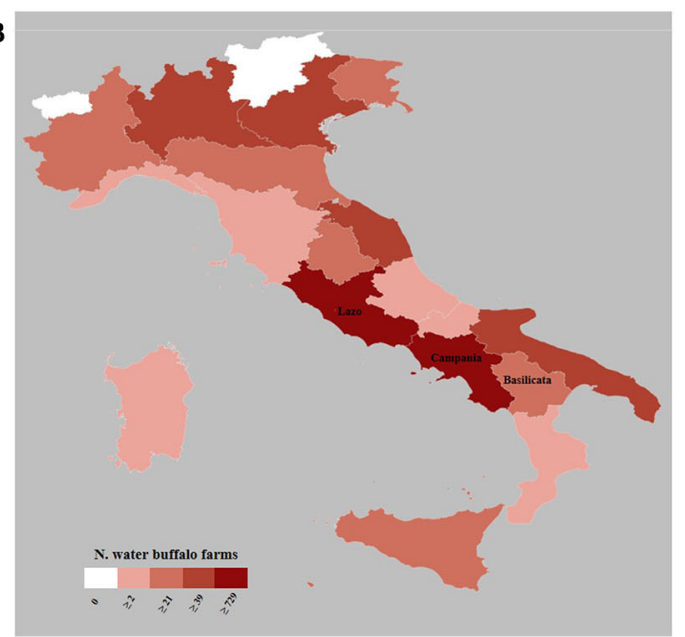

FIGURE 2 | Maps of distribution of cattle (A) and buffalo (B) farms in Italy at 31th December 2019 (data by National Data Bank).

are the regions with the highest percentage of the total buffalo farms in Italy with $26.9 \%$ and $48.8 \%$, respectively (NDB at 31 th December 2019).

\section{Copromicroscopic Analysis}

A total of 72,620 fecal samples were collected directly from the rectum of animals involved in the study. In each farm, 
individual fecal samples (at least $20 \mathrm{~g}$ ) from 20 animals were collected according to three age groups: 5 calves (0-6 months), 5 heifers ( $7-12$ months) and 10 adults ( $>12$ months). The collected samples were stored by vacuum packaging (30) and sent to the laboratories of CREMOPAR. In the laboratory for each farm, 4 pools of feces (one for calves, one for heifers, and two for adults) were prepared, taking $5 \mathrm{~g}$ of each individual fecal sample (31). Pooled samples were analyzed by the FLOTAC technique with an analytic sensitivity of 2 OPG, using a sodium chloride flotation solution (specific gravity $=1,200)(32)$.

In order to sporulate the oocysts and identify the Eimeria species, the fecal samples from each positive farm (OPG $\geq 50$ ) were pooled into one sample (at least $10 \mathrm{~g}$ ), diluted 1:10 with a $2.5 \%$ potassium dichromate solution and incubated in a container at $26-28^{\circ} \mathrm{C}$ for one week, oxygenating the samples several times a day (33). The Eimeria species were identified using the morphometric keys of Eckert et al. (34) and de Noronha et al. (33).

\section{Statistical Analysis}

Chi-square $\left(\chi^{2}\right.$-test) was employed to verify the association between prevalence and age group of animals and between prevalence of different Eimeria species and regions for both hosts. One-way ANOVA test was performed to detect OPG variability between seasons through the years. Difference was considered significant at $P<0.05$. These statistical analyses were performed with SPSS 23.0 software (IBM, Armonk, NY, USA).

\section{RESULTS}

\section{Prevalence of Eimeriosis}

Eimeria spp. was found in both cattle and water buffaloes showing a prevalence of $91.7 \%$ (95\% confidence interval, $95 \%$ $\mathrm{CI}=90.2-93.1)$ in cattle farms and $81.5 \%(95 \% \mathrm{CI}=79.8-83.1)$ in water buffalo farms with statistically significant difference $(P<0.05)$. In buffaloes from Lazio, the prevalence was higher than in the Campania region with a statistically significant difference $(P<0.05)$. Regarding OPG, the overall mean value was 66.8 in cattle and 55.9 in water buffaloes, but this difference was not statistically significant $(P>0.05)$. These results were represented in Figures 3A,B. The highest prevalence rate and OPG mean values were recorded in young animals (Table 1). The one-way ANOVA test showed that calves had OPG values significantly higher $(P<0.05)$ in both cattle and buffalo farms.

\section{Yearly Prevalence and Seasonal Dynamics of Infection}

Yearly prevalence of positive farms to Eimeria infection showed a mean of $86.4 \%$ in cattle farms and $82.1 \%$ in water buffalo farms. A higher coccidiosis prevalence $(100 \%)$ was reported in cattle farms from 2012 to 2013, in water buffalo farms from 2012 to 2014. Despite the high prevalence of eimeriosis registered every year, a trend of decrease was recorded in the last three years (from 2017 to 2019) in both hosts.

The general pattern of the excreted mean OPG was very irregular in both hosts. From 2010 to 2013, the values recorded in cattle and water buffaloes were similar, while the highest OPG values were reported in cattle in 2017 and in water buffaloes in 2016.

Although the annual mean prevalence was highest in spring $(86.9 \%)$ in cattle farms while in water buffalo farms was highest in summer $(82.4 \%)$ and winter $(82.3 \%)$, no statistically significant differences $(P>0.05)$ between seasons were found in either hosts.

\section{Identification of Eimeria Species}

Nine species of Eimeria were found in cattle and eight in water buffaloes (Table 2). E. bovis and E. zuernii, the most pathogenic species in cattle, were present in both hosts and in all the three studied regions. E. bareillyi, host-specific and pathogenic for buffalo, was found in Lazio and Campania regions with a prevalence of 13.0 and $11.0 \%$, respectively. Mixed infections were common in both livestock species; in particular, $71.2 \%$ of cattle and $39.4 \%$ of water buffalo farms were infected with more than one Eimeria species. In cattle, the prevalence of E. subspherica, E. zuernii, E. bovis, E. canadensis, and E. alabamensis was higher $(P<0.05)$ in Basilicata than in the Campania region.

\section{DISCUSSION}

The 10-year surveillance program indicates that eimeriosis is common (up to 100\%) in cattle and water buffaloes in the Mediterranean area studied as in different parts of the world $(5,7,8,11,13,15,35,36)$. The overall prevalence of Eimeria spp. was higher in cattle farms (91.7\%) than in water buffalo farms (81.5\%). These findings could be explained by the best management practices of modern intensive water buffalo breeding. In particular, the mean coccidiosis prevalence in cattle farms reported in the Campania region in our study $(88.3 \%)$ was lower than the value of $100 \%$ detected in a previous study performed in extensive farms in southern Italy (20). For water buffalo farms, the mean prevalence (80.6\%), in the decade 2010-2019, showed a small reduction compared to $97.7 \%$ reported in the previous decade (2000$2009)$ in the Campania region $(21,37)$. Therefore, these results are in agreement with the earlier findings of the 10-year analysis, showing that the epidemiology of Eimeria spp. in this study area has changed over time with a slight reduction in the last three years. This decrease may be due to a control plan implemented by CREMOPAR which started in 2014 through the Rural Development Programme (38) of Campania Region aimed to promote regular and accurate parasitological diagnosis, treatment strategy, and dissemination of best practices of management to cattle and water buffalo farmers. Nonetheless, Eimeria is still widespread in the cattle and water buffalo farms.

The mean OPG value was $66.8(\min =2$; $\max =8,065)$ in cattle and $55.9(\min =2 ; \max =15,415)$ in water buffaloes, but this difference was not statistically significant $(P>0.05)$. The mean OPG levels were statistically higher in calves (174.3) than in adult animals (43.2), in both livestock hosts, in agreement with other studies performed in cattle in different countries as 
A
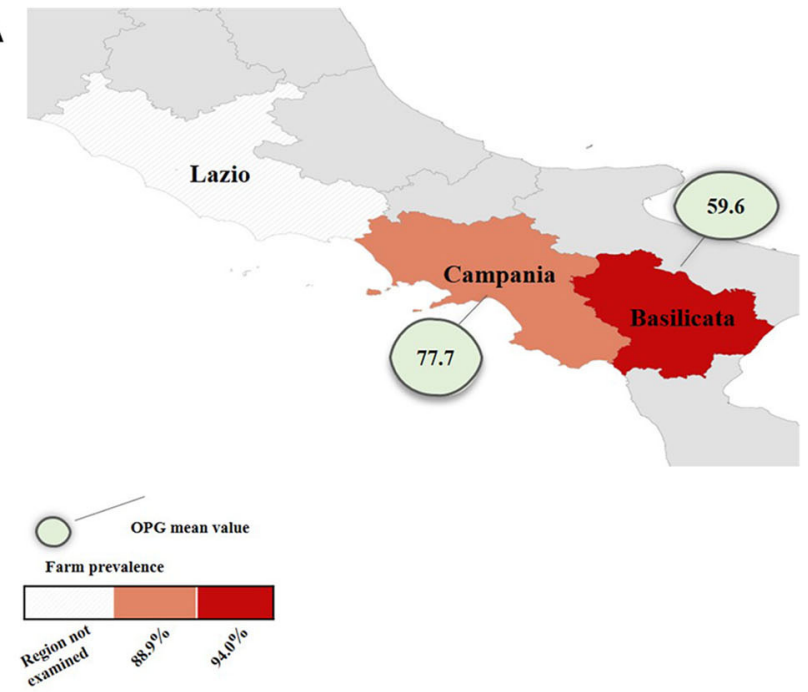

B

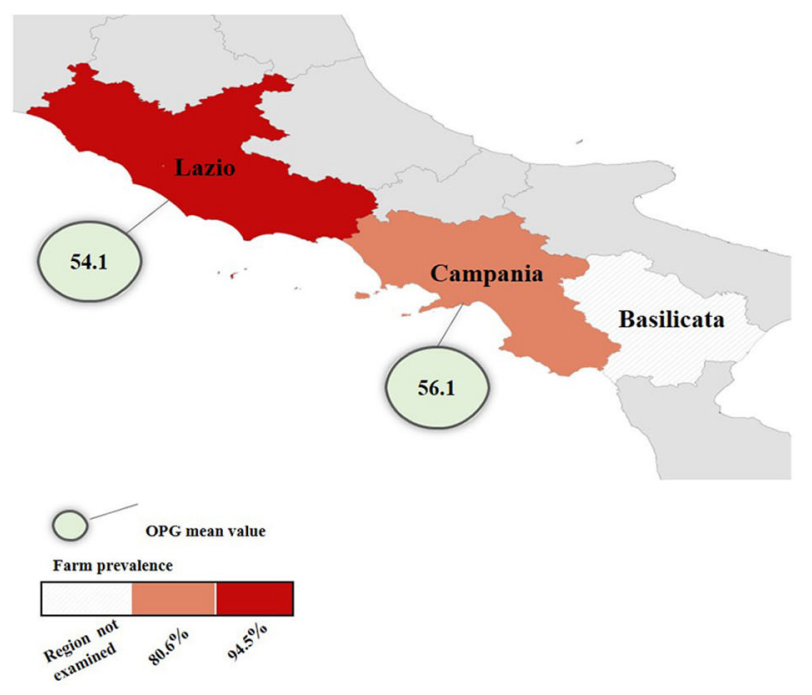

FIGURE 3 | Maps of farm prevalence and OPG mean value of cattle (A) in Basilicata and Campania and water buffalo (B) farms in Lazio and Campania.

TABLE 1 | Farm prevalence (95\% Cl) of Eimeria spp., age-group mean OPG, minimum, and maximum OPG values, in cattle farms in Campania and Basilicata regions and in buffalo farms in Lazio and Campania regions.

\begin{tabular}{|c|c|c|c|c|c|c|c|}
\hline \multirow[t]{3}{*}{ Region } & \multirow[t]{3}{*}{ Host } & \multirow[t]{3}{*}{ Farm prevalence $\%(95 \% \mathrm{Cl})$} & \multicolumn{5}{|c|}{ Oocysts per gram of feces (farm prevalence\%) } \\
\hline & & & \multicolumn{3}{|c|}{ Mean (prevalence\%) } & \multirow[t]{2}{*}{ Minimum } & \multirow[t]{2}{*}{ Maximum } \\
\hline & & & Calves & Heifers & Adults & & \\
\hline Campania & Cattle & $88.9(86.1-97.1)$ & $167.2(61.0)$ & $65.6(67.8)$ & $40.1(38.8)$ & 2 & 8,065 \\
\hline Basilicata & Cattle & 94.0 (92.2-95.4) & $188.3(89.9)$ & $47.4(87.7)$ & $45.6(39.8)$ & 2 & 8,005 \\
\hline
\end{tabular}

Pakistan (39), Germany (40), Kenya (5), and Mexico (7) and in water buffaloes in Brazil (33) and in Pakistan (41). The results of seasonality showed there were no significant differences between the seasons.

Some authors found statistically significant differences between seasons and prevalence in animals $(1,7,8,35,41$, 42 ), but in the Mediterranean area the large ruminant farming system is mainly intensive and so the presence of Eimeria might not be influenced by the weather or by grazing, but rather by overcrowding and herd management (e.g., hygiene of pens).

The most prevalent species of Eimeria found in this study were E. bovis (67.9\%), E. ellipsoidalis (39.1\%), E. cylindrica (31.8\%), and E. zuernii (30.3\%) in cattle. These species were widespread also in other countries $(8,12,36,43,44)$, while some species, such as E. pellita, E. bukidonensis, and E. brasiliensis $(7,8,12,43,44)$, were not found in our study. In water buffaloes, E. ellipsoidalis was the most prevalent (36.3\%) species, followed by E. auburnensis (26.7\%), E. bovis (22.3\%), and E. zuernii (18.2\%); in addition, E. bareillyi, the buffalo hostspecific species, showed a prevalence of $12.3 \%$. These Eimeria species were found also in other countries, such as Netherlands,
Egypt, Turkey, Iran, Pakistan, India, and Brazil (13, 35, 45), while E. cylindrica, E. alabamensis, E. canadensis, E. brasiliensis, and E. bukidnonensis found by several authors $(13,35,45)$ were not found in our study. Mixed infections with more than one species were common in cattle and buffalo farms with values of 71.2 and $39.4 \%$, respectively. Of the Eimeria species detected in this study, only E. bovis, E. zuernii, E. auburnensis, and E. bareillyi are responsible of severe clinical disease due to intestinal lesions with effects on the digestive process and overall homeostasis (46). However, the presence of clinical eimeriosis was not assessed in this study and further research is needed to investigate the effects of different species and OPG level on disease development in cattle and buffaloes.

Eimeria species in cattle and water buffalo are identified only through morphological characteristics, but to date there are no studies showing that species in cattle are genetically identical to the ones in water buffaloes. For this reason, molecular techniques using the $18 \mathrm{~S}$ ribosomal RNA (rRNA) region can be used, not only to identify Eimeria species but also to study intra- and inter-genetic variations in cattle and water buffalo species $(47,48)$. The accurate 
TABLE 2 | Prevalence of Eimeria species identified in cattle farms in Campania and Basilicata regions and in water buffalo farms in Lazio and Campania regions.

\begin{tabular}{|c|c|c|c|c|}
\hline \multirow{2}{*}{$\begin{array}{l}\text { Region } \\
\text { Host }\end{array}$} & \multirow{2}{*}{$\begin{array}{c}\text { Basilicata } \\
\text { Cattle }\end{array}$} & \multicolumn{2}{|c|}{ Campania } & \multirow{2}{*}{\begin{tabular}{|c|} 
Lazio \\
Buffalo
\end{tabular}} \\
\hline & & Cattle & Buffalo & \\
\hline \multicolumn{5}{|l|}{ Eimeria species } \\
\hline E. subspherica* & $26.2(20.2-33.1)$ & $12.5(7.1-20.8)$ & $18.7(13.1-25.9)$ & $17.2(10.6-26.4)$ \\
\hline E. cylindrica* & $36.1(29.4-43.4)$ & $26.9(18.9-36.7)$ & 0.0 & 0.0 \\
\hline E. alabamensis ${ }^{*}$ & $6.3(3.4-11.0)$ & $1.0(0.1-6.0)$ & 0.0 & 0.0 \\
\hline E. bovis* & $78.0(71.3-83.5)$ & $57.7(47.6-67.2)$ & $21.3(15.3-28.7)$ & $23.2(15.6-33.0)$ \\
\hline E. canadensis ${ }^{*}$ & $12.0(7.9-17.7)$ & $2.9(0.8-8.8)$ & 0.0 & 0.0 \\
\hline E. wyomingensis* & $7.9(4.6-12.9)$ & $7.7(3.6-15.0)$ & $9.7(5.7-15.7)$ & 0.0 \\
\hline E. bukidnonensis* & 0.0 & 0.0 & 0.0 & 0.0 \\
\hline E. bareillyi & - & - & $11.6(7.2-18.0)$ & $13.0(10.8-15.9)$ \\
\hline
\end{tabular}

*Eimeria species common to cattle and buffalo.

identification of Eimeria species has important implications for disease control (49), selection of treatment strategies [e.g., metaphylactic treatments; (50)], and identification of alternative therapeutic approaches [e.g., ozone and intestinal microbiome; $(51,52)]$.

Metaphylactic treatments with toltrazuril was very useful against Eimeria infections in cattle $(18,50,53)$, as well as in water buffaloes (19), showing improved performances in animals (e.g., faster body weight gain, positive influence on the average age at the first birth, increased overall percentage of pregnancies). Moreover, a reduction in oocyst excretion was demonstrated, with particular reference to the two species considered to be mainly responsible for clinical coccidiosis (E. zuernii and E. bovis) (18). Therefore, the metaphylactic approach should also contribute to the reduction in environmental contamination with oocysts, limiting the infection pressure $(18,54)$. However, the efficacy of toltrazuril could be increasingly reduced by the development of Eimeria resistance in ruminants (55). Thus, new lowcost and eco-friendly anti-Eimeria strategies are urgently required. Alternative therapeutic approaches based on ozone in ruminants (51) could be useful to control Eimeria infections as demonstrated in poultry (56). Moreover, recent studies have highlighted the complex network of interactions occurring between protozoa and the gut commensal flora, showing the potential contribution of the intestinal microbiome in the control of parasitic infections (52).

In conclusion, the findings obtained showed that the coccidiosis is a persistent and complex problem, so a combination of good management practice, affordable diagnostic techniques, and strategic treatments (traditional and/or alternative) could be useful to plan an effective control of Eimeria infections in large ruminants.

\section{DATA AVAILABILITY STATEMENT}

The raw data supporting the conclusions of this article will be made available by the authors, without undue reservation.

\section{ETHICS STATEMENT}

This animal study was reviewed and approved by Ethic Committee of the Department of Veterinary Medicine and Animal Production, University of Napoli Federico II. Written informed consent was obtained from the owners for the participation of their animals in this study.

\section{AUTHOR CONTRIBUTIONS}

LA, GS, GB, GC, and LR contribute to the conception and design of the study. MEM and $\mathrm{AB}$ organized the database. MEM, AB, MPM, and LR wrote the manuscript. MEM and MPM performed the statistical analysis and GIS. All authors contributed to manuscript revision and read and approved the submitted version.

\section{FUNDING}

This study was supported by funds provided by the Italian Ministry of University and Scientific Research for industrial Ph.D. programmes.

\section{ACKNOWLEDGMENTS}

The authors would like to sincerely thank Alessandra Amadesi, Davide Ianniello, Mario Parrilla, Paola Pepe, and Mirella Santaniello for their collaboration. 


\section{REFERENCES}

1. Das M, Deka DK, Sarmah PC, Islam S, Sarma S. Diversity of Eimeria spp. in dairy cattle of Guwahati, Assam, India. Vet World. (2015) 8:941-5. doi: 10.14202/vetworld.2015.941-945

2. Dubey JP. Re-evaluation of endogenous development of Eimeria bareillyi gill, Chhabra and Lall, 1963 in water buffalo (Bubalus bubalis). Parasitology. (2018) 145:1845-52. doi: 10.1017/S0031182018000604

3. Keeton STN, Navarre CB. Coccidiosis in large and small ruminants. Vet Clin North Am Food Anim Pract. (2018) 34:201-8. doi: 10.1016/j.cvfa.2017.10.009

4. Lassen B, Lepik T, Järvis T. Seasonal recovery of Eimeria oocysts from soil on naturally contaminated pastures. Parasitol Res. (2014) 113:993-9. doi: 10.1007/s00436-013-3731-6

5. Makau DN, Gitau GK, Muchemi GK, Thomas LF, Cook EAJ, Wardrop NA, et al. Environmental predictors of bovine Eimeria infection in western Kenya. Trop Anim Health Prod. (2017) 49:409-16. doi: 10.1007/s11250-016-1209-0

6. Lee SH, Kim HY, Lee H, Kim JW, Lee YR, Chae MJ, et al. Eimeria species in cattle with diarrhoea in the Republic of Korea regarding age, season and nature of diarrhea. Vet Rec. (2018) 183:504. doi: 10.1136/vr.104600

7. Alcala-Canto Y, Figueroa-Castillo JA, Ibarra-Velarde F, Vera-Montenegro Y, Cervantes-Valencia ME, Alberti-Navarro A. First database of the spatial distribution of Eimeria species of cattle, sheep and goats in Mexico. Parasitol Res. (2019) 119:1057-74. doi: 10.1007/s00436-019-06548-8

8. Lopez-Osorio S, Villar D, Failing K, Taubert A, Hermosilla C, ChaparroGutierrez, et al. Epidemiological survey and risk factor analysis on Eimeria infections in calves and young cattle up tolyear old in Colombia. Parasitol Res. (2020) 119:255-66. doi: 10.1007/s00436-019-06481-w

9. Cringoli G, Guarino A, Fusco G, Veneziano V, Rinaldi L. Diffusion dynamics of Eimeria spp. in infected buffalo herds. Parassitologia. (1998) 40:38.

10. Dubey JP. Coccidiosis in water buffaloes Bubalus bubalis. In: Dubey JP, editor. Coccidiosis in Livestock, Poultry, Companion Animals, Humans. Cleveland, OH: CRC Press (2019). p. 91-8. doi: 10.1201/9780429294105-8

11. Tomczuk K, Grzybeka M, Szczepaniaka K, Studzinskaa M, DemkowskaKutrzepaa M, Roczen-Karczmarza M, et al. Analysis of intrinsic and extrinsic factors influencing the dynamics of bovine Eimeria spp. from central-eastern Poland. Vet Parasitol. (2015) 214:22-8. doi: 10.1016/j.vetpar.2015.09.027

12. Cruvinel LB, Nicaretta JE, Bastos TSA, Couto LFM, Santos JBD, Zapa DMB, et al. Eimeria species in dairy and beef cattle of different ages in Goiàs state, Brazil. Rev Bras Parasitol. (2018) 27:169-76. doi: 10.1590/s1984-296120180038

13. Dubey JP. A review of coccidiosis in water buffaloes (Bubalus bubalis). Vet Parasitol. (2018) 256:50-7. doi: 10.1016/j.vetpar.2018.04.005

14. Reddy S, Sivajothi S, Rayulu, VC. Clinical coccidiosis in adult cattle. J Parasit Dis. (2015) 39:557-9. doi: 10.1007/s12639-013-0395-1

15. Bangoura B, Bardsley, KD. Ruminant coccidiosis. Vet Clin North Am Food Anim Pract. (2020) 36:187-203. doi: 10.1016/j.cvfa.2019.12.006

16. Ciuca L, Borriello G, Bosco A, D'Andrea L, Cringoli G, Ciaramella P, et al. Seroprevalence and clinical outcomes of Neospora caninum, Toxoplasma gondii and Besnoitia besnoiti infections in water buffaloes (Bubalus bubalis). Animals. (2020) 10:532. doi: 10.3390/ani10030532

17. Veronesi F, Diaferia M, Viola O, Piergili Fioretti D. Long-term effect of toltrazuril on growth performances of dairy heifers and beef calves exposed to natural Eimeria zuernii and Eimeria bovis infections. Vet J. (2011) 190:296-9. doi: 10.1016/j.tvjl.2010.10.009

18. Veronesi F, Nisoli L, Diaferia M, Falcini R, Ficola E, Piergili Fioretti D. Influence of a metaphylactic treatment with Baycox $($ Bovis on the reproductive performances of Fresian heifers: a preliminary study. Parasitol Res. (2013) 112:2137-42. doi: 10.1007/s00436-013-3373-8

19. Bosco A, Rinaldi L, Cappelli G, Saratsis A, Nisoli L, Cringoli G. Metaphylactic treatment strategies with toltrazuril and diclazuril and growth performance of buffalo calves exposed to a natural Eimeria infection. Vet Parasitol. (2015) 212:408-10. doi: 10.1016/j.vetpar.2015.06.034

20. Rinaldi L, Veneziano V, Santaniello M, Schioppi M, Musella V, Cringoli G. I coccidi del genere Eimeria in bovini semibradi. Large Anim Rev. (2004) $10: 13-8$.

21. Bosco A, Rinaldi L, Maurelli MP, Cringoli G. Parasitological scenario of buffalo farms in central southern Italy: a review. In: Presicce GA, editor.
The Buffalo (Bubalus bubalis)-Production Research. Sharjah: Bentham e-books (2017). p. 298-312. doi: 10.2174/9781681084176117010014

22. Bangoura B, Mundt HC, Schmäschke R, Westphal B, Daugschies A. Prevalence of Eimeria bovis and Eimeria zuernii in German cattle herds and factors influencing oocyst excretion. Parasitol Res. (2011) 109:129-38. doi: 10.1007/s00436-011-2409-1

23. Raue K, Heuer L, Böhm C, Wolken S, Epe C, Strube C. 10-year parasitological examination results (2003 to 2012) of faecal samples from horses, ruminants, pigs, dogs, cats, rabbits and hedgehogs. Parasitol Res. (2017) 116:3315-30. doi: 10.1007/s00436-017-5646-0

24. World maps of köppen-geiger climate classification. Available online at: http:// koeppen-geiger.vu-wien.ac.at/ (accessed April 23, 2020).

25. Gilbert M, Nicolas G, Cinardi G, Van Boeckel TP, Vanwambeke, et al. Global distribution data for cattle, buffaloes, horses, sheep, goats, pigs, chickens and ducks in 2010. Sci Data. (2018) 5:180227. doi: 10.1038/sdata.2018.227

26. Guerci M, Bava L, Zucali M, Sandrucci A, Penati C, Tamburini A. Effect of farming strategies on environmental impact of intensive dairy farms in Italy. J Dairy Res. (2013) 80:300-8. doi: 10.1017/S0022029913000277

27. Pdo Buffalo Mozzarella Drives Italian Cheese Export. Available online at: https://news.italianfood.net/2017/02/07/pdo-buffalo-mozzarella-drivesitalian-cheese-export/ (accessed February 24, 2020).

28. Cringoli G, Musella V, Maurelli MP, Morgoglione M.E, Santaniello $\mathrm{A}$, Condoleo $\mathrm{R}$, et al. Helminths and arthropoda in buffalo farms from the Lazio region (Italy). Vet Res Comm. (2009) 33:129-31. doi: 10.1007/s11259-009-9268-6

29. European Commission. Available online at: https://ec.europa.eu/commission/ presscorner/detail/en/IP_96_492 (accessed April 23, 2020).

30. Rinaldi L, Coles GC, Maurelli MP, Musella V, Cringoli G. Calibration and diagnostic accuracy of simple flotation, McMaster and FLOTAC for parasite egg counts in sheep. Vet Parasitol. (2011) 177:345-52. doi: 10.1016/j.vetpar.2010.12.010

31. Rinaldi L, Amadesi A, Dufourd E, Bosco A, Gadanho M, Lehebel A, et al. Rapid assessment of faecal egg count and faecal egg count reduction through composite sampling in cattle. Parasit Vectors. (2019) 12:353. doi: 10.1186/s13071-019-3601-x

32. Cringoli G, Rinaldi L, Maurelli MP, Utzinger J. FLOTAC: new multivalent techniques for qualitative and quantitative copromicroscopic diagnosis of parasites in animals and humans. Nat Protoc. (2010) 5:503-15. doi: $10.1038 /$ nprot.2009.235

33. de Noronha AC, Starke-Buzetti WA, Duszynski DW. Eimeria spp. in Brazilian water buffalo. J Parasitol. (2009) 95:231-4. doi: 10.1645/GE-1605.1

34. Eckert J, Taylor M, Catchphole J, Licois D, Coudert P, Bucklar H. Morphological characteristics of oocysts. In: Eckert J, Braun R, Shirley MW, Coudert P, editors. COST 89/820 - Biotechnology - Guidelines on Techniques in Coccidiosis Research. Luxembourg: European Commission (1995) p. 103-17.

35. Gupta A, Singh NK, Singh H, Rath, SS. Assessment of risk factors associated with prevalence of coccidiosis in dairy animals of Punjab. J Parasit Dis. (2016) 40:1359-64. doi: 10.1007/s12639-0150690-0

36. Gebeyehu B, Kebede E, Kifleyohannes T, Abebe N, Kumar N. Prevalence of calf coccidiosis in Mekelle, Northern Ethiopia. Ethiopian Vet J. (2018) 22:1-13. doi: 10.4314/evj.v22i2.1

37. Ghanem MM, Radwaan ME, Moustafa AM, Ebeid MH. Comparative therapeutic effect of toltrazuril, sulphadimidine and amprolium on Eimeria bovis and Eimeria zuernii given at different times following infection in buffalo calves (Bubalus bubalis). Prev Vet Med. (2008) 84:161-70. doi: 10.1016/j.prevetmed.2007.12.013 (accessed April 23, 2020).

38. The European Network for Rural Development (ENRD). Available online at: https://enrd.ec.europa.eu/country/italy_en (accessed April 23, 2020).

39. Rehman TU, Khan MN, Sajid MS, Abbas RZ, Arshad M, Iqbal Z, et al. Epidemiology of Eimeria and associated risk factors in cattle of district Toba Tek Singh, Pakistan. Parasitol Res. (2011) 108:1171-7. doi: 10.1007/s00436-010-2159-5

40. Bangoura B, Mundt HC, Schmäschke R, Westphal B, Daugschies A. Prevalence of Eimeria bovis and Eimeria zuernii in German cattle herds and factors influencing oocyst excretion. Parasitol Res. (2012) 110:875-81. doi: 10.1007/s00436-011-2569-z 
41. Khan MN, Rehman TU, Sajid MS, Abbas RZ, Zaman MA, Sikandar A, et al. Determinants influencing prevalence of coccidiosis in Pakistani buffaloes. Pakistan Vet J. (2013) 33:287-90.

42. Saratsis A, Joachim A, Alexandros S, Sotiraki S. Lamb coccidiosis dynamics in different dairy production systems. Vet Parasitol. (2011) 181:131-8. doi: 10.1016/j.vetpar.2011.04.027

43. Koutny H, Joachim A, Tichy A, Baumgartner W. Bovine Eimeria species in Austria. Parasitol Res. (2012) 110:1893-901. doi: 10.1007/s00436-0112715-7

44. Enemark HL, Dahl J, Enemark JM. Eimeriosis in Danish dairy calves-correlation between species, oocyst excretion and diarrhoea. Parasitol Res. (2013) 112:169-76. doi: 10.1007/s00436-013-3441-0

45. El-Alfy E, Abbas IE, Al-Kappany Y, Al-Araby M, Abu-Elwafa SA, Dubey JP. Prevalence of Eimeria species in water buffaloes (Bubalus bubalis) from Egypt and first report of Eimeria bareillyi oocysts. J Parasitol. (2019) 105:748-54. doi: 10.1645/19-58

46. Daugschies A, Najdrowski M. Eimeriosis in cattle: current understanding. $J$ Vet Med B Infect Dis Vet Public Health. (2005) 52:417-27. doi: 10.1111/j.1439-0450.2005.00894.x

47. Carvalho FS, Wenceslau AA, Teixeira M, Albuquerque GR. Molecular diagnosis of Eimeria species affecting naturally infected Gallus gallus. Genet Mol Res. (2011) 10:996-1005. doi: 10.4238/vol10-2gmr1043

48. Koreeda T, Kawakami T, Okada A, Hirashima Y, Imai N, Sasai K, et al. Pathogenic characteristics of a novel intranuclear coccidia in Japanese black calves and its genetic identification as Eimeria subspherical. Parasitol Res. (2017) 116:3243-7. doi: 10.1007/s00436-017-5629-1

49. Carvalho FS, Wenceslau AA, Teixeira M, Matos Carneiro JA, Melo AD, Albuquerque GR. Diagnosis of Eimeria species using traditional and molecular methods in field studies. Vet Parasitol. (2011) 176:95-100. doi: 10.1016/j.vetpar.2010.11.015

50. Zechner G, Bauer C, Jacobs J, Goossens L, Vertenten G, Taylor MA, et al. Efficacy of diclazuril and toltrazuril in the prevention of coccidiosis in dairy calves under field conditions. Vet Rec. (2015) 176:126. doi: 10.1136/vr.1 02237
51. Duričić D, Valpotić H, SamardŽija M. Prophylaxis and therapeutic potential of ozone in buiatrics: current knowledge. Anim Reprod Sci. (2015) 159:1-7. doi: 10.1016/j.anireprosci.2015.05.017

52. Burgess SL, Gilchrist CA, Tucker CL, Petri WA Jr. Parasitic protozoa and interactions with the host intestinal microbiota. Infect Immun. (2017) 85:e00101-17. doi: 10.1128/IAI.00101-17

53. Philippe P, Alzieu JP, Taylor MA, Dorchies PH. Comparative efficacy of diclazuril (Vecoxan $($ ) and toltrazuril (Baycox bovis $($ ) ) against natural infections of Eimeria bovis and Eimeria zuernii in French calves veterinary parasitology December. Vet Parasitol. (2014) 206:129-37. doi: 10.1016/j.vetpar.2014.10.003

54. Daugschies A, Agneessens J, Goossens L, Mengel H, Veys P. The effect of a metaphylactic treatment with diclazuril (Vecoxan) on the oocyst excretion and growth performance of calves exposed to a natural Eimeria infection. Vet Parasitol. (2007) 49:199-206. doi: 10.1016/j.vetpar.2007.08.003

55. Odden A, Denwood MJ, Snorre S, Robertson JL, Ruiz A, Hamnes IS, et al. Field evaluation of anticoccidial efficacy: a novel approach demonstrates reduced efficacy of toltrazuril against ovine Eimeria spp. in Norway. Int J Parasitol Drugs Drug Resist. (2018) 8:304-11. doi: 10.1016/j.ijpddr.2018.05.002

56. Liou CT, Wang JS, Ooi HK. Effect of ozone treatment on Eimeria colchici oocysts. J Parasitol. (2002) 88:159-62. doi: 10.1645/0022-3395.2002. 088[0159:EOOTOE]2.0.CO;2

Conflict of Interest: The authors declare that the research was conducted in the absence of any commercial or financial relationships that could be construed as a potential conflict of interest.

Copyright (c) 2020 Morgoglione, Bosco, Maurelli, Alves, Saralli, Bruni, Cringoli and Rinaldi. This is an open-access article distributed under the terms of the Creative Commons Attribution License (CC BY). The use, distribution or reproduction in other forums is permitted, provided the original author(s) and the copyright owner(s) are credited and that the original publication in this journal is cited, in accordance with accepted academic practice. No use, distribution or reproduction is permitted which does not comply with these terms. 